\title{
How Does Colonial Origin Matter for Economic Performance in Sub- Saharan Africa?
}

\author{
Julius A. Agbor*
}

April 2011

\begin{abstract}
This paper investigates some of the existing hypotheses regarding the transmission of different colonial legacies to modern day economic growth. The fact that different colonial strategies were pursued by different colonizers in various territories suggests possible ramifications for current development paths. This paper attempts to understand why economic growth performance is different even among African countries, where former British colonies appear to do marginally better. It focuses on two key channels of transmission, namely education and trade. Thirty-six Sub-Saharan African countries during the period 1960-2000 are considered using Hausman-Taylor estimation techniquein an annualized panel data framework. In contrast with the methodology of previous studieswhere only the initial conditions at independence were held to influence the post-colonialgrowth path, this study attempts to distinguish the direct .../
\end{abstract}

Keywords: colonial origin, education, institutions, Hausman-Taylor, Sub-Saharan Africa

JEL classification: F54, O47, I20, N17

\section{Copyright （C) UNU-WIDER 2011}

*University of the Western Cape, email: juliusagbor2002@yahoo.fr

This study has been prepared within the UNU-WIDER project on Africa Development: Myths and Realities, directed by Augustin Fosu.

UNU-WIDER gratefully acknowledges the financial contributions to the project by the Finnish Ministry for Foreign Affairs, and the financial contributions to the research programme by the governments of Denmark (Royal Ministry of Foreign Affairs), Finland (Finnish Ministry for Foreign Affairs), Sweden (Swedish International Development Cooperation Agency-Sida) and the United Kingdom (Department for International Development-DFID). 
influences of colonization from the indirect influences by combining both the initial conditions at independence alongside the subsequent post-independence changes in explaining growth differences amongst former Sub-Saharan African colonies.The results suggest that the indirect influences of colonial educational policies matter more for post-colonial growth than the direct influences.

\section{Acknowledgements}

With the usual disclaimer, I am greatly indebted to my previous co-authors of this paper, Johannes Fedderke and Nicola Viegi, for their invaluable input. I am also indebted to Nathan Nunn, Mariotti Martine, Manoel Bittencourt, Ruthira Naraidoo, and two anonymous referees, for detailed and immensely helpful comments on different versions of this paper. I would also like to thank participants at the following conferences: 2011 Annual Conference of the American Economic Association in Denver, 2010 Annual Conference of the Centre for the Study of African Economies at Oxford, UNU-WIDER Project Conference on African Economic Development: Myths and Realities (December 2009 in Accra), Economic Society of South Africa Conference (September 2009 in Port Elisabeth), and Macro Workshop Seminar Series of the School of Economics (August 2009 at the University of Cape Town), for helpful comments. Financial support received from the A. W. Mellon Foundation Fellowship and the African Economic Research Consortium is gratefully acknowledged.

The World Institute for Development Economics Research (WIDER) was established by the United Nations University (UNU) as its first research and training centre and started work in Helsinki, Finland in 1985. The Institute undertakes applied research and policy analysis on structural changes affecting the developing and transitional economies, provides a forum for the advocacy of policies leading to robust, equitable and environmentally sustainable growth, and promotes capacity strengthening and training in the field of economic and social policy making. Work is carried out by staff researchers and visiting scholars in Helsinki and through networks of collaborating scholars and institutions around the world.

www. wider.unu.edu publications@wider.unu.edu

UNU World Institute for Development Economics Research (UNU-WIDER)

Katajanokanlaituri 6 B, 00160 Helsinki, Finland

Typescript prepared by Lisa Winkler at UNU-WIDER

The views expressed in this publication are those of the author(s). Publication does not imply endorsement by the Institute or the United Nations University, nor by the programme/project sponsors, of any of the views expressed. 


\section{Introduction}

Over the past decades, a substantial volume of literature has dwelled on the subject of colonization and economic performance of former colonies. Economists became interested in colonial legacies in their search for the reasons why some countries have grown relatively slower than others. Notably, recent cross-country empirical evidence suggests that the identity of the colonizing power (or colonial origin) might help explain the observed growth differential amongst former colonies around the world. ${ }^{1}$ In particular, it is claimed that on average, former British colonies have grown faster than former French colonies although much controversy still surrounds the likely mechanisms of transmission of any such colonial legacy.

For instance, Klerman et al.(2008)results, using a sample of 49 former colonies around the world during 1960-2003, found that differences in educational policies is the main reason why former British colonies have grown faster than former French colonies. In addition, Klerman et al.(2008) show that colonial origin does not matter after geographical factors are controlled for, which lends support to the initial endowments hypothesis 2 that differences in the initial conditions of pre-colonization rather than in colonial policy (legal, educational, or other) are the best explanation for different growth rates amongst former colonies. However, Klerman et al.'s(2008) results, as they themselves admit, are inconclusive, due to their high sensitivity to regional considerations and to the choice of sample considered. ${ }^{3}$ To be thorough on this, I choose to focus mainly on the Sub-Saharan African (SSA) sample of countries which does not seem to suggest an important difference in initial geographical conditions between the former British and French colonies.

Another contribution to an understanding of the channels of transmission between colonial origin and growth is in the works of Rostowski and Stacescu (2006; 2008), althoughthe primary focus of their study, likeKlerman et al. (2008), is not on the channels per se, but rather on the primacy between legal origin versus colonial origin on growth. Like Klerman et al. (2008), Rostowski and Stacescu(2006; 2008) also find that colonial origin matters more than legal origin and education is the likely channel through which colonial origin affects growth. In the context of this study, the main problem with the Rostowski and Stacescu papers, as with the Klerman et al. paper, is that they do not probe into the different mechanisms through which colonial origin affects growth and their analyses are limited to the initial conditions at independence. Remarkable in the conclusion ofthe Rostowski and Stacescu paper is the suggestion that: 'examining the channels through which colonial origin could affect growth is therefore the first priority for future research'.(Rostowski and Stacescu 2006: 17).

The other empirical studies that investigate the impact of colonial heritage on growth documented in the literature have mainly focused either on the channel of initial

1 See for instance, the works by Klerman et al. (2008), Rostowski and Stacescu (2006; 2008), Price (2003), Bertocchi and Canova (2002), and Grier (1999).

2 Pioneered in the works of Engerman and Sokoloff (2002).

3 For instance, Klerman et al. (2008) admit that their results controlling for geographical factors are highly dependent on their definition of the regional dummies for Latin America and SSA and on which set of countries is analysed. 
geographical conditions 4 (or betterstill, the disease environment)or on the legal channel. 5

The objective of this paper is to investigate further on the channels through which colonial origin affects economic growth performance, focusing only on the SSA sample. Besides limiting the sample of study to a set of countries which does not suggest any important difference in the impact of initial geographical conditions, this paper goes beyond all the previous studies by distinguishing the direct effects of colonial legacies from the indirect effects. In other words, attempting to separate the initial independence conditions from the subsequent changes introduced by the independent African states.

The sample of study comprises 36 SSA countries during the period 1960-2000 using the Hausman-Taylor (HT) estimation technique in an annualized panel data framework. We investigate two likely transmission channels between colonial origin and growth, namely, education and trade. In contrast with the methodology of previous studieswhere only the initial conditions at independence were held to influence the postcolonialgrowth path, this study attempts to distinguish the direct influences of colonization from the indirect influences by combining both the initial conditions at independence alongside the subsequent post-independence changes in explaining growth differences amongst former SSA colonies. In other words, the rationale for including the initial conditions at independence, alongside the subsequent postindependence changes is to distinguish whether what really mattered was the persistence of initial conditions left by the colonizers, or whether the evolution of the society after independence had any significant impact on post-independence growth performance. Or betterstill, 'removing' the impact of the history of the colonizer so as to see whether the changes that the newly independent nations 'added on' could separately explain the economic growth path of different countries.

The results suggest that the indirect influences of colonial educational policies matter more for post-colonial growth than the direct influences. The results further suggest that former British SSA colonies have grown marginally faster than former French colonies during 1960-2000, and this is attributable to the favourable contribution of the indirect influence of the legacy of British colonization in education. I do not find any evidence in support of the trade transmission mechanism. The empirical literature has recently emphasized the specific colonial policy of education as the likely transmission mechanism between colonial origin and growth but none of the previous studies, to the best of my knowledge, have differentiated the direct effects of the legacy of colonial educational policy from the indirect effects. By suggesting that the post-independence education conditions matter more than the initial independence education conditions,

4 See for instance, Price (2003), Acemoglu, Johnson, and Robinson (2001), Easterly and Levine (2003), and Rodrik, Subramanian, and Trebbi (2002).

5 The protagonists of this debate are La Porta, Lopez-de-Silanes, Shleifer, and Vishny, (1997; 1998; 1999) and La Porta, Lopez-de-Silanes, and Shleifer (2008). See also Mahoney (2001) and Levine, Loayza, and Beck (2000), Levine, Beck, and Demirgüç-Kunt (2002). These cross-country studies show that countries that followed the English Common Law legal tradition, by colonization or conquest, have on average grown faster than countries that followed the Civil Law tradition specifically, the French Civil Law countries. However, recent evidence as shown in the works of Acemoglu and Johnson (2005) and Klerman et al. (2008) suggests that legal origin cannot explain economic growth performance. Roe and Siegel (2009), also present a range of conceptual and factual evidence in support of why the legal origins explanations are flawed. 
this evidence contradicts the findings of previous studies, which suggest that the independence education conditions alone are a statistically significant determinant of the post-colonial growth path.

Furthermore, the results suggest that although education has been largely detrimental to post-colonial growth performance in SSA, former British colonies do marginally better than former French colonies because the inherited educational system is more akin to produce development. These findings suggest that the choices made by European colonizers during the colonization of Africa, notably, in educational policies, continue to matter today and are a crucial determinant of growth differences across the continent.

The rest of the paper is organized as follows. Section 2 provides a brief historical overview of the likely mechanisms of transmission at work between colonial origins and growth, while Section 3 presents the methodology of the study. Section 4 discusses the key findings and checks for their robustness and also compares my results to those in the literature, notably by Klerman et al. (2008), Rostowski and Stacescu (2006; 2008), Bertocchi and Canova (2002), and Grier (1999), while Section 5 concludes.

\section{Historical overview of the likely mechanisms of transmission between colonial origins and growth}

Historical sources claim that as of the late nineteenth century, Britain was the only imperial power that was committed to free trade, whilst the other European powers, notably France, were still building up their rival industries through protectionism. ${ }^{6}$ Correspondingly, whilst British colonial economies were not under the obligation to export only to Britain, French colonial economies were compelled to trade mainly with France. ${ }^{7}$ As such, it can be argued that one of the important legacies of British colonization on its former colonies has been a long exposure to world competition through trade openness, ${ }^{8}$ which might possibly explain why former British SSA colonies adjusted more rapidly to structural adjustment programmes implemented in the late 1980s in comparison with their French counterparts. ${ }^{9}$

Another important legacy of colonization, which has found much lesser expression in the cross-country empirical growth literature, is the distortionary impact of different colonial taxation systems on private investment incentives. 10 Historical sources ${ }^{11}$ claim

6 Grier (1999) reports that, Britain had had a free trade policy from 1830, and as from 1846, British colonies were no longer forced to give British goods preferential treatment. Hence these colonies have had a long history of free trade, while the French enforced mercantilist and protectionist measures throughout the colonial period. For additional evidence see also, Maddison (1971), Bolton (1973), and Gannand Duignan (1970).

7 See Fieldhouse (1966).

8 During the inter-war period, Nigeria alone exported five times as much as all the French colonies in West Africa(Rostowski and Stacescu 2006).

9 The evidence also points to the fact that former British SSA colonies grew much faster than French SSA colonies after structural adjustment.

10 The few existing works are single country studies, notably, Banerjee and Iyer (2005) on India and Berger (2009) on Nigeria.

11 See for instance, Crowder (1968) and Asiwaju (2000). 
that the dual system of administration of their colonies, characterized by punitive taxation and forced labour on the general population, was a distinctive feature of French colonial rule in SSA. ${ }^{12}$ The implication of this unique approach to local administration is to be found in the colonial legacy of taxation pursued in the post-colonial era. By contrast, Maddison (1971) has argued that one of the important legacies of British colonization is that its former colonies inherited relatively lower levels of taxation, because indirect rule is cheaper to administer compared to direct rule, which was characteristic of French colonial rule. Austin (2008) also argues that until very late in the colonial period, there was no direct taxation in southern Ghana and Nigeria-two of the most successful British colonies in tropical Africa. If this is true, then it could imply that former British colonies are associated with relatively lower degrees of distortions of economic activity through taxation, which could in turn imply greater private investment incentives or more free trade on the domestic scale.

Furthermore, it is well documented that educational policy was potentially the area of greatest distinction between different imperial colonial administrations. It is generally claimed that Britain pursued more enlightened educational policies in its colonies than did France, whose educational objective aimed essentially at training personnel for the colonial bureaucracy. For instance, Gann and Duignan (1970: 354), argue that

Mission teachers in British Africa not only taught their pupils how to read and write, but also taught them how to try their hands at many different jobs because the teachers themselves, besides giving lessons, were also engaged in such diverse activities as constructing their own buildings, cultivating their own crops, experimenting in agriculture and building roads.

In addition, it is widely held that primary instruction in former British colonies was administered through village schools using native teachers and the local vernacular languages of the people, whilst in former French colonies, pupils were generally boarded from their homes to far away schools where they were taught in French by French teachers, using French textbooks. This is suggestive of a different approach to educational provision with different repercussions on post-independence human capital accumulation, and development.

Finally, an important colonial legacy that also merits further attention in the empirical literature is the impact of the Franc CFA ${ }^{13}$ currency board which links France to most of its former SSA colonies. This, especially as Julan (2010) has recently shown that being part of the Franc FCA currency board increases the likelihood of currency crisis which might impede economic performance. The Franc CFA currency board, it is also argued, has been instrumental in lowering inflation and the black market exchange premium while enhancing the contribution of imports to GDP growth. However, as the evidence suggests, the impact of the currency board on economicperformance could go the other

12 Crowder (1968) argues that the 'code d'indigénat', which was instituted in French SSA aimed at achieving the employment of native labour through the imposition of relatively high taxes on blacks and in default of payment they would incur a sentence of forced labour.

13 The Franc CFA stands for Franc de la Communauté Financiere en Afrique, meaning Financial Community of Africa Franc. 
way. ${ }^{14}$ Thus, a major distinction between the former British and French SSA colonies has been the fact that almost all former British SSA colonies have floating exchange regimes, whereas, almost all former French SSA colonies operate under a fixed exchange regime.

In summary, this paper will focus primarily on two likely channels of transmission between colonial origins and growth.

- The education or human capital channel, which will be proxied by two variables, namely, secondary enrolment rates during 1960-2000 (SEC), and the average years of schooling in the population aged 15 and above during 19602000 (AYS).

- The trade channel, which will be proxied by the export share in GDP during 1960-2000 (EXP) and openness to international trade during 1960-2000 (OPEN).

\section{Methodology}

\subsection{Empirical model}

The questions I seek to answer in this paper are whether colonial origin really matters for post-independence economic growth in SSA, and if yes, what are its channels of transmission?

To answer these questions, I specify the regression model as follows

$$
\begin{aligned}
\text { GROW }_{i t}=\alpha & +\beta_{i} \text { COLO }_{i}+\gamma_{i} \text { TRANSM }_{i t}+\eta_{i} \text { INTERACT }_{i t}+\delta_{i} \text { CONTROLS }_{i t}+\mu_{i} \\
& +\varepsilon_{i t}(1)
\end{aligned}
$$

where

- GROW $W_{i t}$ is the per capita GDP growth during 1960-2000,

- $\mathrm{COLO}_{i}$ is a matrix of colonial origin dummies comprising BCORG (which takes the value 1 for British colonial origin and zero otherwise), FCORG (which takes the value 1 for French colonial origin and zero otherwise) and PCORG (which takes the value 1 for Portuguese former coloniesand zero otherwise) and BECORG (which takes the value 1 for Belgian former coloniesand zero otherwise), ${ }^{15}$

- TRANSM $M_{i t}$ is a matrix of control variables that serve as likely transmission channels between colonial origin and growth,

14 For instance, one of the main arguments for devaluing the Franc CFA by 50 per cent in January 1994, was because of its excessively distortionary effects on the economies of those countries. See Collier and Gunning (1999).

15 Of course, only three of the colonial origin dummies enter the regression at a time, while the fourth dummy serves as base. 
- INTERACT $T_{i t}$ is a matrix of interaction terms linking colonial origin dummies $\left(\mathrm{COLO}_{i}\right)$ with the transmission mechanisms $\left(T R A N S M_{i t}\right)$. A model with interaction terms can be presented in a simplified form as

$$
Y=a+b X_{1}+c X_{2}+d X_{1} X_{2}+\mu_{i}
$$

Where $X_{1}$ and $X_{2}$ represent the matrix of transmission channels and the vector of colonial origin dummies respectively. Thus, $\frac{\partial Y}{\partial X_{1}}=b+d X_{2}$ tells us whether the impact of a specific transmission channel is significantly different across colonial origins.

- CONTROLS $i t$ is a matrix of control variables that are standard in the growth literature, in addition to controls for the duration of colonization,

- $\mu_{i}$ is a vector of individual country effects reflecting unobservable country heterogeneity, and $\varepsilon_{i t}$ is a vector of error terms.

\subsection{Choice of estimator}

I perform my analysis on the empirical model specified in Equation (1), using a core dataset of thirty-six SSA countries during 1960-2000. A key consideration in choosing a suitable estimator for the model is how well the estimator handles the problem of endogeneity resulting from the fact that some of the explanatory variables might be correlated with the unobserved country effects. As Baltagi (2001) argues, the fixed effects (within) estimator assumes that all the explanatory variables are related to the individual effects and the within-estimator is a best linear unbiased estimator (BLUE) once the individual effects are modelled as a linear function of all the explanatory variables. Using the within-transformation (henceforth FE) in estimating Equation (1) above, results in the elimination of the $\mu_{i}$ term, and hence the bias. However, the FE also eliminates the time-invariant regressors, and is therefore incapable of giving estimates of $\beta_{i}$ and $\gamma_{i}$.

The random-effects (RE) model, on the other hand, assumes no correlation between the explanatory variables and the individual effects, implying that, in the presence of endogeneity RE will yield biased estimates. Hence, inferences from the RE model are likely to be misleading. This is equally true for the OLS estimator, which also assumes exogeneity of all regressors and the random individual effects.

Against these two contrasting worlds of all or nothing correlation between the individual effects and the regressors, Hausman and Taylor (1981) in Baltagi, Bresson, and Pirotte (2003) proposed a model where some of the regressors, but not all, are correlated with the individual effects. The HT model thus bridges the two extreme worlds of all (FE world) or nothing (RE world) choice of correlation between the individual effects and the regressors. As Baltagi, Bresson, and Pirotte(2003) have argued, the HT model is preferable whenever the model requires some of the regressors, but not all, to be correlated with the individual effects.

The HT model can be written as

$$
y_{i t}=\beta X_{i t}+\varphi Z_{i}+\alpha_{i}+\mu_{i t}
$$

where $i=1,2, \ldots . N$ and $t=1,2, \ldots$. T. while $\alpha_{i}$ is $\operatorname{IID}\left(0, \sigma_{\mu}^{2}\right)$. 
Both $\alpha_{i}$ and $\mu_{i t}$ are independent of each other and among themselves. The $Z_{i}$ are individual time-invariant variables.

Hausman and Taylor split $X=\left[X_{1}, X_{2}\right]$ and $Z=\left[Z_{1}, Z_{2}\right]$ into two sets of variables such that $X_{1}$ is $n \times k_{1}, X_{2}$ is $n \times k_{2}, Z_{1}$ is $n \times g_{1}, Z_{2}$ is $n \times g_{2}$, and $n=N T$.

$X_{1}$ and $Z_{1}$ are assumed exogenous and not correlated with $\alpha_{i}$ and $\mu_{i t}$, while $X_{2}$ and $Z_{2}$ are endogenous due to their correlation with $\alpha_{i}$ but not with $\mu_{i t}$.

Under Equation (2), OLS will yield biased and inconsistent estimates, while the FE (or within-transformation) estimator gives consistent estimates. The FE sleeps the $\alpha_{i}$ and removes the bias, but, in the process, it also eliminates the time-invariant variables, $Z_{i}$. Hence it cannot yield estimates of $\varphi$. The RE estimator, which is a generalized least square estimation on Equation (2), ignores the endogeneity due to the presence of the $\alpha_{i}$ term and will therefore yield biased though consistent estimates.

To get around the shortcomings of the within-estimator in estimating the time-invariant regressors, Hausman and Taylor suggest an instrumental variable estimator which premultiplies Equation (2) by $\Omega^{\frac{-1}{2}}$ where $\Omega$ is the variance-covariance term of the error component $\alpha_{i}+\mu_{i t}$, and then performs two-stage least squares (2SLS) using as instruments $\left[Q, X_{1}, Z_{1}\right] . Q$ is the within-transformation matrix with $\tilde{y}=Q y$ having a typical element $\tilde{y}_{i t}=y_{i t}-\bar{y}_{i}$ where $\bar{y}_{i}$ is the individual mean. As Baltagi, Bresson, and Pirotte(2003) show, this turns out to be equivalent to running 2SLS with $\left[\tilde{X}, \bar{X}_{1}, Z_{1}\right]$ as the set of instruments. 16

It is important to emphasize that the order of identification $k_{1} \geq g_{2}$ must hold for Equation (2) to be non-singular. In other words, the number of time-varying exogenous regressors $X_{1}$ must be at least as large as the number of individual time-invariant endogenous regressors $Z_{2}$. Specifically, the model is said to be just-identified, when $k_{1}=g_{2}$ and in this case, the HT estimates of $\varphi$ are equivalent to estimates obtained from 2SLS estimation. The model is said to be over-identified, when $k_{1}>g_{2}$ and in this case, the HT estimates of $\varphi$ are more efficient than estimates obtained from the FE estimator. Finally, the model is under-identified when $k_{1}<g_{2}$ and in this case, the HT model cannot provide estimates of $\varphi$.

\subsection{Estimation strategy}

In order to answer the question whether colonial origin matters for economic growth in SSA, I specify a simple growth model in which the only explanatory variables are the various colonial origin dummies (BCORG, FCORG, PCORG, and BECORG). This is easily achieved using OLS with robust standard errors.

To determine which transmission mechanisms are at work, I include variables that capture the different transmission channels, alongside their corresponding interaction

16 Baltagi, Bresson, and Pirotte (2003) also argue that the HT estimator is based on an instrumental variable estimator which uses both the between and within variation of the strictly exogenous variables as instruments. More specifically, the individual means of the strictly exogenous regressors are used as instruments for the time-invariant regressors that are correlated with the individual effects, as in Baltagi (2001). 
terms with colonial origin dummies. To distinguish the direct effects of colonization (i.e. impacts of colonial legacies measured in the year of independence) from the indirect effects (i.e. the impacts the additional changes brought in by the independent African states), I include for each transmission channel considered, the time-invariant values measured in the year of independence and the time-variant values measured throughout the period of analysis. I also include control variables that are standard in the growth literature in addition to controls for the duration of colonization. I test for robustness of the results by using alternative proxies for the transmission channels and alternative estimation techniques, as well as different time intervals (five-year and tenyear period averages). The dependent variable in all model specifications is the annual growth rate of per capita GDP during 1960-2000.

Thus, the principal explanatory variables in each model specification are the timeinvariant educational and trade variables measured in the year of independence of each country included in the sample, the corresponding time-variant educational and trade variables alongside their corresponding interaction terms with colonial origin dummies. A statistically significant sign on the time-invariant educational and trade variables measured in the year of independence would suggest a strong direct influence of the transmission channels on post-colonial growth, while a statistically significant sign on the time-variant educational and trade variables would suggest a strong indirect influence of the transmission mechanism and vice versa.

Irrespective of the nature of the influence of the channel (direct or indirect), it would be important to know whether the impact of the channel is identical across the board for all colonial origins or it matters disparately across colonial origins - which is the role of the interaction terms between the transmission variables and colonial origin dummies in the regression models.

\subsection{Variables and data}

The dependent variable in all model specifications is the per capita GDP growth during 1960-2000 (GROW). Amongst the explanatory variables, I include the colonial origin dummies. I classify the SSA countries in the sample into four broad colonial origin families: (i) British colonial origin (BCORG) for colonies that acquired their independence from Britain, (ii) French colonial origin (FCORG) for countries that acquired independence from France, (iii) Portuguese colonial origin (PCORG) for countries that acquired their independence from Portugal, and (iv) Belgian colonial origin (BECORG) for countries that acquired their independence from Belgium. By basing colonial origin on the identity of the colonizer through which independence was acquired, I am assuming in line with the tradition in the literature, that it is the colonial power that granted independence that significantly shaped the country's post-colonial future. ${ }^{17}$ Countries that witnessed a relatively short period of colonization (e.g. Ethiopia)

17 This might be a significant limitation, especially for those countries that had more than one European colonial experience. This is especially true for Cameroon and all the former German colonies (Togo, Tanzania, and Namibia). One way to get around this limitation is to add another set of dummy variables capturing 'prior colonizers'. However, this option leaves me with another problem-that of a small sample - as a result of the reduced degrees of freedom. Furthermore, this detail adds less to the analysis. Admittedly, including the 'prior colonizers' would add substantially to the results only where the first colonizer stayed for a significant period. This is perhaps true only for South Africa, 
or which were never colonized (e.g. Liberia) are excluded from the sample. Furthermore, countries that had multiple colonization experiences with the experience of the previous colonizers impacting for a significant period of the country's colonial history (e.g. South Africa) are also excluded. I also exclude Cape Verde and the Comoros Islands for lack of consistent data. Table 1 provides a classification of the countries in the dataset together with their dates of colonization and independence.

Besides the colonial origin dummies, the other choice explanatory variables are a set of variables that capture the two transmission mechanisms between colonial origin and growth. These are:

- The gross secondary enrolment rates during 1960-2000 (SEC) to capture the education or human capital transmission channel. The conventional growth literature suggests that human capital enhancement is good for growth either because it raises the overall productivity of the economy or because it favours the development of pro-growth institutions. ${ }^{18}$ However, this evidence is inconclusive as other empirical studies, notably by Pritchett (2001), suggest that growth in human capital could be detrimental for per capita GDP growth. The interaction terms of colonial origin with secondary enrolment rates during 1960 2000, are SEC_BRI, SEC_FRE, SEC_POR and SEC_BEL, for British, French, Portuguese, and Belgian colonial origins respectively. I also include the timeinvariant secondary enrolment rates measured in the year of independence of each country included in the sample (SEC_IND). For robustness, I use an alternative measure of education, namely, the average schooling years in population aged 15 years and above. Hence, the independence measure for average schooling years is AYS_IND, while the post-colonial measure (AYS) and its interaction terms are given by (AYS_BRI, AYS_FRE, AYS_POR, and AYS_BEL).

- The average share of exports in GDP during 1960-2000 (EXP) to capture the trade transmission mechanism. The literature suggests that SSA countries that were more open to trade have indeed grown faster than those that were not. ${ }^{19}$ Rodrik (2002) however holds a dissenting view. Thus, the sign on exports in the regressions can go either way. The interaction terms of colonial origin with exports during 1960-2000 are EXP_BRI, EXP_FRE, EXP_POR, and EXP_BEL, for British, French, Portuguese, and Belgian colonial origins respectively. Similarly, the export measure in the year of independence of the country is represented by EXP_IND. Where necessary, I use openness to international markets as alternative proxy for the trade channel.

Furthermore, I introduce another set of six control variables that are standard in the growth literature. These are:

- The natural logarithm of initial real per capita GDP in 1960 (LOGPCGDP60) to capture convergence effects. Quah (1993) argues that due to the problem of

which had a long Dutch tenure followed by extended British rule, but I have excluded this case from the sample.

18 For instance, Easterly and Levine (1997) and Glaeser, Lopez-de-Silanes, and Shleifer (2004) find a positive contribution of human capital to GDP growth in their regressions.

19 See, for instance, Sachs and Warner (1997). 
reversion to the mean, the sign on initial per capita income can either be positive or negative depending on the sample.

- The growth rate of population during 1960-2000 (GPO) to control for the effect of demographic factors on growth. I follow the endogenous growth literature, notably by Kremer (1993) in suggesting a possible correlation between labour force growth (proxied by population growth) and income growth and the two are expected to be positively correlated. Solow (1956) and Swan (1956) suggest the opposite.

- The inflation rate during 1960-2000 (INFL) to capture the negative effects of price instability on growth. Hayek (1944) and Friedman (1977) in Grier (1999: 322) both claim that inflation uncertainty increases price variability, thus harming economic growth.

- The average share of real investment ${ }^{20}$ in GDP purchasing power parity during 1960-2000 (INV) to account for the contribution of physical capital accumulation in GDP growth. The standard neoclassical growth literature suggests that investment in physical capital is good for growth during transitional dynamics, although this might not be the case at steady states. The expected sign on INV in the regressions should therefore be positive.

- An annual index of the black market exchange rate premium during 1960-2000 (BMP) to capture the effects of market distortion that might be detrimental to growth. Easterly and Levine (1997) find a strong negative association between black market premiums and growth.

- Finally, a measure of the ethno-linguistic fractionalization (ETHNIC). The expected sign of ETHNIC in the growth regression is negative, according to the evidence from Easterly and Levine (1997) and Mauro (1995).

In addition to this set of control variables, I introduce a variable, DUREE, to capture the duration of colonial rule. DUREE is obtained by subtracting the respective country independence year from the year that the country was first colonized. ${ }^{21}$ Table 2 summarizes the definition of variables and sources.

Finally, I indicate the à priori classification of these variables into the various HT categories. The HT model requires classification of variables into the following four categories, namely, time-variant exogenous variables, time-invariant exogenous variables, time-variant endogenous variables and time-invariant endogenous variables. However, the latter category need not be included for the model to be correctly specified.

Based on economic theory, I classify the variables into the HT model as exogenous due to their supposed non-correlation with both the unobserved individual effects $\left(\alpha_{i}\right)$ and with the error term $\mu_{i t}$. Similarly, I classify some variables as endogenous in the model because of their supposed correlation with $\alpha_{i}$ but not with $\mu_{i t}$. I thus regroup the variables into the following four HT categories viz.

20 The variable includes both private and public investment.

21 It would have been consistent to take into account only the year that the last colonizer arrived (for those countries that had multiple colonization experiences) but this detail would not add much to the present analysis. 
- Time variant exogenous variables: the black market exchange rate premium during 1960-2000 (BMP). Following Easterly and Levine (1997), I classify black market exchange premium as exogenous in the HT model because it tends to capture growth-inhibiting institutional imperfections that might not necessarily be correlated with the individual country effects.

- Time variant endogenous variables: secondary enrolment rates during 19602000 (SEC), average years of schooling during 1960-2000 (AYS), export share in GDP during 1960-2000 (EXP), investment during 1960-2000 (INV), inflation during 1960-2000 (INFL), and population growth during 1960-2000 (GPO). Accordingly, all the interaction terms for education and trade enter in this category. Following the tradition in the empirical growth literature, we classify these variables as endogenous in the HT model.22

- Time invariant endogenous variables: secondary enrolment rates at independence (SEC_IND), average schooling years at independence (AYS_IND), and export share in GDP at independence (EXP_IND).

- Time invariant exogenous variables: all colonial origin dummies23 (BCORG, FCORG, PCORG, and BECORG), the duration of colonial rule (DUREE), the natural logarithm of initial per capita GDP in 1960 (LOGPCGDP60), and ETHNIC.

Table 3 provides summary descriptive statistics of variables included in the sample while Table 4 provides the partial correlation coefficients. Most of my data come from the Global Development Finance and the World Development Indicators. The partial correlation results below suggest that the duration of colonization is strongly positively correlated with the education and trade variables, and the independence education measures (SEC_IND and AYS_IND) are also strongly positively correlated with the post-independence education variables (SEC and AYS, respectively), which suggests a strong persistence of colonial educational practices in the post-colonial era. This is also true for the independence trade (EXP_IND) and post-independence trade (EXP) variables.

\section{Discussion of results}

The discussion of the results follows the two-stage empirical strategy. Accordingly, I first analyse stage one results based on simple OLS estimation and then proceed to stage two results based on the HT estimator.

\subsection{Stage one results based on simple OLS}

Table 5 presents the results from three model specifications of Equation (1). Model 1 includes only colonial origin dummies as explanatory variables for growth and tests the hypothesis that colonial origin matters for growth in SSA. The results suggest that, indeed, colonial origin matters and former British SSA colonies have grown on average

22 For instance, Glaeser, Lopez-de-Silanes, and Shleifer (2004) treat human capital as endogenous while Rostowski and Stacescu (2006) treat both human capital and openness as endogenous in their regressions.

23 The intuition for placing colonial origin dummies in this category is mainly because of selection effects. 
roughly 1 percentage point faster than former French colonies. However, there seems to be no significant difference in growth between the former French, Portuguese, or Belgian SSA colonies.

Model 2, includes, in addition to the colonial origin dummies, the transmission mechanisms investigated (trade measured by EXP and EXP_IND and education measured by SEC and SEC_IND), controls for the duration of colonization and all the other controls that are standard in growth models. The former British colonial origin dummy (BCORG) loses all of its statistical significance and also diminishes in magnitude while the former Portuguese colonial origin dummy (PCORG) gains statistical as well as economic significance. This result suggests that former Portuguese colonies have grown averagely 7 percentage points faster than former French colonies. Of the two transmission mechanisms tested, only the education channel appears to matter while the trade channel is insignificant. Of the two education channel variables, only SEC is statistically significant (at 1 per cent level), although negative, suggesting that the indirect influence of colonial educational policies matters more than the direct influence. This result also suggests that the contribution of human capital development to SSA growth during 1960-2000 has generally been detrimental, which is Pritchettconsistent.

Model 3 tests the robustness of the results in Model 2 by using an alternative measure of the education channel, namely, the average schooling years in the population aged 15 and above (AYS and AYS_IND). The results in Model 3 basically uphold the results of Model 2 with the only difference that both the direct and indirect effects of colonial educational policies matter for post-independence growth performance. However, the direct effects of the legacy of colonial education have had a positive repercussion while the indirect effects have had a negative repercussion. In other words, the legacy of colonial education practices per se, has had positive repercussions on post-independence growth while the additional changes brought in by the independent African states have had a negative effect on growth.

The findings from these different model specifications give an idea of the possible transmission channel between colonial origin and growth in SSA. However, because of the bias and inconsistency of OLS estimation, this evidence is inconclusive and requires further investigation using alternative techniques and measurement.

\subsection{Stage two results based on HT estimation}

Table 6 presents the results from four model specifications of Equation (1). Model 1 includes, in addition to the colonial origin dummies, the transmission channelvariables (trade measured by EXP24and education measured by SEC and SEC_IND), controls for the duration of colonization, and all the other controls that are standard in growth models. The results suggest that only the education channel matters and of the two education channel variables analysed, only SEC is statistically significant (at 1 per cent level), although negative, suggesting that the post-independence educational policies of

24 Based on the preliminary results of the OLS estimation presented above, only the education transmission channel merits further detailed empirical investigation. An additional reason for dropping the independence trade variable (EXP_IND) is to enable comparability of my results to those of previous studies. 
the former colonies are largely responsible for the observed growth differences amongst these countries. In other words,the indirect influence of colonial educational policies matters more than the direct influence.The lack of statistical significance on the independence education variable (SEC_IND) suggests that the initial education conditions of SSA countries at independence cannot be held in explaining growth differences amongst former SSA colonies during 1960-2000. This result contradicts the findings of previous studies, notably, the works of Klerman et al. (2008), Rostowski and Stacescu (2006, 2008), Bertocchi and Canova (2002), and Grier (1999) where the independence education conditions are found to be the main determinants of the postcolonial growth path.

The results in Model 2 which controls for possible differences in post-independence educational policies across colonial origins reveal a positive and highly statistically significant (at 1 per cent) sign on the British colonial origin post-independence education interaction term (SEC_BRI) suggesting that, in comparison with former French colonies, the post-independence education conditions in former British SSA colonies have been more favourable to growth. In other words, the reason why former British SSA colonies appear to do better than former French colonies is because the indirect influence of British colonial education legacy is more akin to produce development than the indirect influence of French colonial education legacy.

The results in Models 3and 4 tests the robustness of the results in Models 1 and 2 respectively, by using an alternative measure of the education channel, namely, the average schooling years in the population aged 15 and above (AYS and AYS_IND). The results in Model 3 basically uphold the results of Model 1 while the results of Model 4 uphold that of Model 2. In other words, the indirect influence of colonial educational policies matter more for growth than the direct influence and former British colonies do comparatively better than former French colonies because of a superior legacy of education inherited from Britain. Another important inference from the results in Table 6 is that, the direct influence of colonial educational practices, has positive (although statistically insignificant) repercussions on post-independence growth while the indirect influences (or additional changes brought in by the independent African states) have negative repercussions on growth.

It is worth mentioning that I repeated the empirical strategy employed in this study using a panel every five and every ten years of all variables that span through 19602000 and obtained similar results. I do not report these results here due to space constraints, however, they are available on request.

In conclusion, it is worth recalling that only one of the two transmission channels explored has survived after subjection to alternative techniques, time frame of analysis, and to alternative proxies, namely, the education channel. I do not find any evidence in support of the trade channel.

\section{Conclusion}

This paper sought to investigate whether colonial origin really matters for economic growth in SSA during 1960-2000 and if it does, what its likely transmission mechanisms are. Two likely channels of transmission, education and trade, were investigated. The methodology that has been applied in this study is slightly different to 
that of previous works, where only initial conditionsat independence were held to influence the subsequent growth path. In contrast, this study attempts to distinguish the direct influences of colonization from the indirect influences by combining both the initial conditions at independence alongside the subsequent post-independence changes in explaining growth differences amongst former SSA colonies.

The results suggest that the indirect influences of colonial educational policies matter more for post-colonial growth than the direct influences. The results further suggest that former British SSA colonies have grown marginally faster than former French colonies during 1960-2000, and this is attributable to the favourable contribution of the indirect influence of the legacy of British colonization in education. In other words, education has a larger positive effect on growth in former British colonies, in comparison to former French colonies. These findings suggest that the choices made by European colonizers during the colonization of Africa, notably, in educational policies, continue to matter today and are a crucial determinant of growth differences across the continent. I do not find any evidence in support of the trade transmission mechanism.

The empirical literature has recently emphasized the specific colonial policy of education as the likely transmission mechanism between colonial origin and growth, but none of the previous studies, to the best of my knowledge, have differentiated the direct effects of the legacy of colonial educational policy from the indirect effects. By suggesting that the post-independence education conditions matter more than the initial independence education conditions, this evidence contradicts the findings of previous studies, which suggest that the independence education conditions alone are a statistically significant determinant of the post-colonial growth path. Further research should consider extending the sample of study to former colonies beyond SSA.

\section{References}

Acemoglu, D.,and Johnson, S.(2005). 'Unbundling Institutions'. Journal of Political Economy, 113(5): 949-95.

Acemoglu, D., Johnson, S., andRobinson, J. A. (2001). 'The Colonial Origins of Comparative Development: An Empirical Investigation'. American Economic Review, 91: 1369-401.

Asiwaju, A. I.(ed.)(2000). West African Transformations: Comparative Impact of French and British Colonialism. Ikeja: Malthouse Press Ltd.

Austin, G. (2008). 'The "Reversal of Fortune" Thesis and the Compression of History: Perspectives from African and Comparative Economic History'. Journal of International Development, 20: 996-1027.

Banerjee, A., and Iyer, L.(2005). 'History, Institutions and Economic Performance: The Legacy of Colonial Land Tenure Systems in India'. The American Economic Review, 95 (4): 1190-213.

Baltagi, B. H. (2001). 'Econometric Analysis of Panel Data'. Chichester: Wiley.

Baltagi, B.H., Bresson, G., and Pirotte, A.(2003).'Fixed Effects, Random Effects or Hausman-Taylor? A Pretest Estimator’. Economic Letters, 79: 361-9. 
Berger, D.(2009). 'Taxes, Institutions and Local Governance: Evidence from a National Experiment in Colonial Nigeria’. PhD Dissertation. New York:New York University. Available at: homepages.nyu.edu/ db1299/Nigeria.pdf (accessed 31March 2011).

Bertocchi, G.,and Canova, F.(2002). 'Did Colonisation Matter for Growth? An Empirical Exploration into the Historical Causes of Africa's Underdevelopment'. European Economic Review, 46: 1851-71.

Bolton, G. C. (1973). Britain’s Legacy Overseas. Oxford: Oxford University Press.

Collier, P.,and Gunning, J. W.(1999). 'Explaining African Economic Performance'. Journal of Economic Literature, 64-111.

Crowder, M.(1968). 'West Africa under Colonial Rule'. London: Hutchinson \& Co Publishers Ltd.

Easterly, W.(2002). The Elusive Quest for Growth: Economists Adventures and Misadventures in the Tropics. Cambridge, MA: MIT Press.

Easterly, W., and Levine, R.(1997). ‘Africa’s Growth Tragedy: Policies and Ethnic Divisions'.Quarterly Journal of Economics, 112(4): 1203-50.

Engerman, S.L., and Sokoloff,K. L.(2002). 'Factor Endowments, Inequality, and Paths of Development among New World Economies’. Economia, 3(1): 41-109.

Fieldhouse, D. K.(1966). The Colonial Empires from the 18th Century. New York: Dell Publishing.

Gann, L.H.,and Duignan, P.(1970). Colonialism in Africa, 1870-1960. Cambridge: Cambridge University Press.

Glaeser, L. P., Lopez-de-Silanes,R., and Shleifer, A. (2004). 'Do Institutions Cause Growth?’. Working Paper 10568.Cambridge, MA: NBER.

Grier, R.(1999). 'Colonial Legacies and Economic Growth’. Public Choice, 98: 317-35.

Julan, D.(2010). 'Institutional Quality and Economic Crisis: Legal Origin Theory Versus Colonial Strategy Theory'. The Review of Economics and Statistics, 92 (1): 173-9.

Klerman, D., Mahoney, P., Spamann, H.,and Weinstein,M.(2008). 'Legal Origin and Economic Growth'. Unpublished Manuscript. Available at: http://www.law.ucla.edu/docs/klerman_paper.pdf

Kremer, M.(1993). 'Population Growth and Technological Change: One Million B.C. to 1990’. Quarterly Journal of Economics, 108 (3): 681-716.

La Porta, R., Lopez-de-Silanes, F., Shleifer, A., and Vishny, R. W.(1997). 'Legal Determinants of External Finance’. The Journal of Finance, LII, (3): 1131-50.

La Porta, R., Lopez-de-Silanes, F., Shleifer, A., and Vishny, R. W.(1998). 'Law and Finance'. Journal of Political Economy, 106 (6): 1113-55.

La Porta, R., Lopez-de-Silanes, F., Shleifer, A., and Vishny, R. W.(1999). 'The Quality of Government'.Journal of Law Economics and Organizations, 15: 222-79.

Levine, R., Loayza, N., andBeck, T.(2000). 'Financial Intermediation and Growth: Causality and Causes'. Journal of Monetary Economics, 46(1): 31-77. 
Levine, R., Beck, T., Demirgüç-Kunt,A.(2002). 'Why Does Legal Origin Matter?'. Policy Research Working Paper 2904. Washington, DC: World Bank.

Maddison, A.(1971). Class Structure and Economic Growth. London: George Allen and Unwin Ltd.

Mahoney, P. G.(2001). 'The Common Law and Economic Growth: Hayek Might be Right'. Journal of Legal Studies, 30 (2): 503-25.

Mauro, P.(1995). 'Corruption and Growth'. Quarterly Journal of Economics, 110(3): 681-712.

Price, G. N.(2003). 'Economic Growth in a Cross-section of Nonindustrial Countries: Does Colonial Heritage Matter for Africa?'. Review of Development Economics, 7 (3): 478-95.

Pritchett, L.(2001). 'Where Has All the Education Gone?'. World Bank Economic Review, 15(3): 367-91.

Quah, D.(1993). 'Galton's Fallacy and Tests of the Convergence Hypothesis'. Scandinavian Journal of Economics, 95(4): 427-43.

Rodrik, D.(2002). 'Trade Strategy, Investment and Exports: Another Look at East Asia'. Pacific Economic Review, 2(1): 1-24.

Rodrik, D., Subramanian, A., and Trebbi, F.(2002). 'The Primacy of Institutions over Geography and Integration in Economic Development'. Working Paper 9305. Cambridge, MA: NBER.

Roe, M. J., and Siegel, J. I. (2009). 'Finance and Politics: A Review Essay based on Kenneth Dam's Analysis of Legal Traditions in the Law-Growth Nexus'. Journal of Economic Literature, 47(3): 781-800.

Rostowski, J.,and Stacescu, B.(2006). 'The Wig and the Pith Helmet - the Impact of "Legal School” versus Colonial Institutions on Economic Performance'. (second version). CASE Network Studies and Analyses 0300. Warsaw: Center for Social and Economic Research.

Rostowski, J.,and Stacescu, B.(2008).'Impact of “Legal School” versus Recent Colonial Origin on Economic Growth'.In A. Aslund and M. Dabrowski (eds), The Challenges of Globalization.Washington, DC: Peterson Institute.

Sachs, J. D.(2003). 'Institutions Don’t Rule: Direct Effects of Geography on Per Capita Income’. Working Paper 9490. Cambridge, MA: NBER.

Sachs, J.D. and Warner, A.(1997). 'Sources of Slow Growth in African Economies'. Journal of African Economies,6: 335-73.

Solow, R. M.(1956). 'A Contribution to the Theory of Economic Growth'. Quarterly Journal of Economics, 70 (1): 65-94.

Swan, T. W. (1956). 'Economic Growth and Capital Accumulation'. Economic Record, 32: 334-61. 
Table 1: List of countries included in the sample

\begin{tabular}{|c|c|c|}
\hline COUNTRY & JCE DATE & DATE OF COLONISATION \\
\hline \multicolumn{3}{|c|}{ FRENCH COLONIAL ORIGIN COUNTRIES, FCORG (15) } \\
\hline Madagascar & 1960 & 1885 \\
\hline Benin & 1960 & 1909 \\
\hline Mali & 1959 & 1898 \\
\hline Mauritania & 1960 & 1903 \\
\hline Burkina Faso & 1960 & 1895 \\
\hline Cameroon & 1960 & 1884 \\
\hline Niger & 1960 & 1861 \\
\hline Central African Republi & 1960 & 1880 \\
\hline Senegal & 1959 & 1758 \\
\hline Chad & 1960 & 1900 \\
\hline Congo Brazzaville & 1960 & 1897 \\
\hline Gabon & 1960 & 1839 \\
\hline Guinea & 1958 & 1898 \\
\hline Ivory Coast & 1960 & 1843 \\
\hline Togo & 1960 & 1914 \\
\hline \multicolumn{3}{|c|}{ BRITISH COLONIAL ORIGIN COUNTRIES, BCORG (16) } \\
\hline Uganda & 1962 & 1885 \\
\hline Botswana & 1966 & 1885 \\
\hline Zambia & 1964 & 1891 \\
\hline Zimbabwe & 1981 & 1890 \\
\hline Malawi & 1964 & 1891 \\
\hline Mauritius & 1968 & 1715 \\
\hline Nigeria & 1960 & 1861 \\
\hline Sierra Leone & 1961 & 1787 \\
\hline Sudan & 1956 & 1796 \\
\hline Swaziland & 1968 & 1902 \\
\hline Namibia & 1990 & 1879 \\
\hline Uganda & 1962 & 1885 \\
\hline Gambia & 1965 & 1765 \\
\hline Ghana & 1957 & 1874 \\
\hline Kenya & 1963 & 1885 \\
\hline Lesotho & 1966 & 1867 \\
\hline \multicolumn{3}{|c|}{ PORTUGUESE COLONIAL ORIGIN COUNTRIES, PCORG (3) } \\
\hline Mozambique & 1975 & 1505 \\
\hline Guinea-Bissau & 1975 & 1505 \\
\hline \multicolumn{3}{|c|}{ BELGIAN COLONIAL ORIGIN COUNTRIES, BECORG (2) } \\
\hline Zaire & 1960 & 1885 \\
\hline Burundi & 1962 & 1903 \\
\hline
\end{tabular}

Source: Price (2003: 481-2). 
Table 2: Variables definition andsources

\begin{tabular}{|c|c|c|}
\hline \multicolumn{3}{|c|}{ VARIABLE LIST \& DESCRIPTION } \\
\hline VARIABLE & DESCRIPTION & SOURCE \\
\hline BCORG & British Colonial Origin dummy & Author \\
\hline FCORG & French Colonial Origin dummy & Author \\
\hline PCORG & Portuguese Colonial Origin dummy & Author \\
\hline BECORG & Belgian Colonial Origin dummy & Author \\
\hline SEC & Post-Colonial Secondary Enrolment Rates (1960-2000) & GDF \&WDI \\
\hline SEC_IND & Independence Secondary Enrolment Rate & GDF \& WDI \\
\hline SEC_BRI & Post-colonial Secondary Enrolment Rates for former British Origin & GDF \&WDI \\
\hline SEC_FRE & Post-colonial Secondary Enrolment Rates for former French Origin & GDF \&WDI \\
\hline SEC_POR & Post-colonial Secondary Enrolment Rates for former Portuguese Origin & GDF \&WDI \\
\hline SEC_BEL & Post-colonial Secondary Enrolment Rates for former Belgian Origin & GDF \&WDI \\
\hline EXP & Post-Colonial Export Share in GDP (1960-2000) & World Bank \\
\hline EXP_IND & Independence Export Share in GDP & World Bank \\
\hline AYS & Post-Colonial Average Schooling Years in Population 15+ (1960-2000) & Barro \& Lee \\
\hline AYS_IND & Independence Average School Years in Population 15+ & Barro \& Lee \\
\hline AYS_BRI & Post-colonial Average School Years in Population 15+ for former British Origin & Barro \& Lee \\
\hline AYS_FRE & Post-colonial Average School Years in Population $15+$ for former French Origin & Barro \& Lee \\
\hline AYS_POR & Post-colonial Average School Years in Population $15+$ for former Portuguese Origin & Barro \& Lee \\
\hline AYS_BEL & Post-colonial Average School Years in Population 15+ for former Belgian Origin & Barro \& Lee \\
\hline GROW & Post-Colonial Per Capita GDP Growth (1960-2000) & World Bank \\
\hline GPO & Post-Colonial Population Growth Rate (1960-2000) & GDF \&WDI \\
\hline LOGPCGDP60 & Per Capita GDP level in 1960 & World Bank \\
\hline DUREE & Duration of Colonisation & Author \\
\hline BMP & Black Market Exchange Premium (1960-2000) & Africa Research Program \\
\hline ETHNIC & Ethno-linguistic Fractionalisation & Africa Research Program \\
\hline INFL & Inflation rate (1960-2000) & World Bank \\
\hline INV & Total Investment share in GDP (1060-2000) & Africa Research Program \\
\hline
\end{tabular}

Source: Author's compilation. 
Table 3: Summary descriptive statistics

\begin{tabular}{|c|c|c|c|c|c|}
\hline Variable & Obs & Mean & Std. dev. & Min. & Max. \\
\hline GROW & 1238 & 6.034893 & 9.458898 & -33.33333 & 92.2078 \\
\hline GPO & 1360 & 2.611742 & .7187012 & -.6744879 & 4.66606 \\
\hline LOGPCGDP60 & 1271 & 7.023608 & .5592167 & 6.045005 & 8.093157 \\
\hline ETHNIC & 1271 & 65.67742 & 22.47371 & 0 & 90 \\
\hline BMP & 1094 & 59.93946 & 282.1426 & -89.16118 & 4806.89 \\
\hline INV & 1350 & 10.35901 & 8.975847 & -2.809372 & 69.91588 \\
\hline INFL & 884 & 54.90318 & 817.2855 & .0123 & 23773.13 \\
\hline DUREE & 1394 & 70.97059 & 15.23022 & 55 & 111 \\
\hline SEC_IND & 1394 & 5.321176 & 7.070332 & 1 & 32.12 \\
\hline SEC & 1379 & 16.71777 & 15.32025 & 1 & 93.117 \\
\hline SEC_BRI & 1379 & 9.566787 & 15.49098 & 0 & 93.117 \\
\hline SEC_FRE & 1379 & 6.153485 & 11.44275 & 0 & 79 \\
\hline SEC_POR & 1379 & .4136563 & 1.981223 & 0 & 21.6 \\
\hline SEC_BEL & 1379 & .581665 & 3.092819 & 0 & 25.7 \\
\hline AYS_IND & 1025 & 1.22084 & .891196 & .17 & 3.172 \\
\hline AYS & 985 & 1.955401 & 1.320378 & .16 & 5.73 \\
\hline AYS_BRI & 985 & 1.313589 & 1.603382 & 0 & 5.73 \\
\hline AYS_FRE & 985 & .4967868 & .8953029 & 0 & 4.68 \\
\hline AYS_POR & 985 & .0256853 & .1355198 & 0 & 1.19 \\
\hline AYS_BEL & 985 & .1193401 & .4368924 & 0 & 3.18 \\
\hline EXP_IND & 1353 & 24.38445 & 17.15794 & 4.861965 & 75.61404 \\
\hline EXP & 1271 & 27.44242 & 16.84334 & 2.524708 & 84.11205 \\
\hline
\end{tabular}

Source: Author's compilation. 
Table 4: Matrix of correlation coefficients

\begin{tabular}{|c|c|c|c|c|c|c|c|c|c|c|c|c|c|c|}
\hline & GROW & GPO & LOGPCGDPGO & ETHNIC & BMP & INV & INFL & DUREE & SEC_IND & SEC & AYS_IND & AYS & EXP_IND & EXP \\
\hline GROW & 1.000 & & & & & & & & & & & & & \\
\hline GPO & 0.113 & 1.000 & & & & & & & & & & & & \\
\hline LOGPCGDPGO & -0.119 & -0.235 & 1.000 & & & & & & & & & & & \\
\hline ETHNC & -0.035 & 0.331 & 0.313 & 1.000 & & & & & & & & & & \\
\hline BMP & -0.023 & -0.026 & -0.024 & 0.025 & 1.000 & & & & & & & & & \\
\hline $\mathbb{N N V}$ & 0.026 & -0.132 & 0.038 & -0.263 & -0.071 & 1.000 & & & & & & & & \\
\hline INFL & -0.001 & 0.057 & -0.028 & 0.087 & 0.031 & -0.087 & 1.000 & & & & & & & \\
\hline DUREE & 0.052 & -0.134 & -0.157 & -0.233 & 0.109 & 0.454 & -0.035 & 1.000 & & & & & & \\
\hline SEC_IND & -0.049 & -0.389 & 0.465 & -0.080 & 0.003 & 0.273 & -0.018 & 0.460 & 1.000 & & & & & \\
\hline SEC & -0.137 & -0.261 & 0.209 & .0 .002 & 0.037 & 0.227 & 0.018 & 0.367 & 0.632 & 1.000 & & & & \\
\hline AYS_IND & .0 .039 & .0 .393 & 0.121 & -0.429 & .0 .045 & 0.467 & .0 .051 & 0.541 & 0.656 & 0.444 & 1.000 & & & \\
\hline AYS & -0.178 & -0.356 & 0.057 & -0.153 & -0.015 & 0.338 & 0.036 & 0.532 & 0.001 & 0.788 & 0.728 & 1.000 & & \\
\hline EXP_IND & -0.080 & -0.061 & 0.206 & 0.300 & -0.004 & 0.067 & -0.006 & 0.287 & 0.530 & 0.493 & 0.174 & 0.491 & 1.000 & \\
\hline EXP & -0.061 & 0.007 & 0.248 & 0.041 & -0.154 & 0.253 & -0.074 & 0.126 & 0.424 & 0.506 & 0.203 & 0.352 & 0.565 & 1.000 \\
\hline
\end{tabular}


Table 5: Preliminary results based on OLS estimation

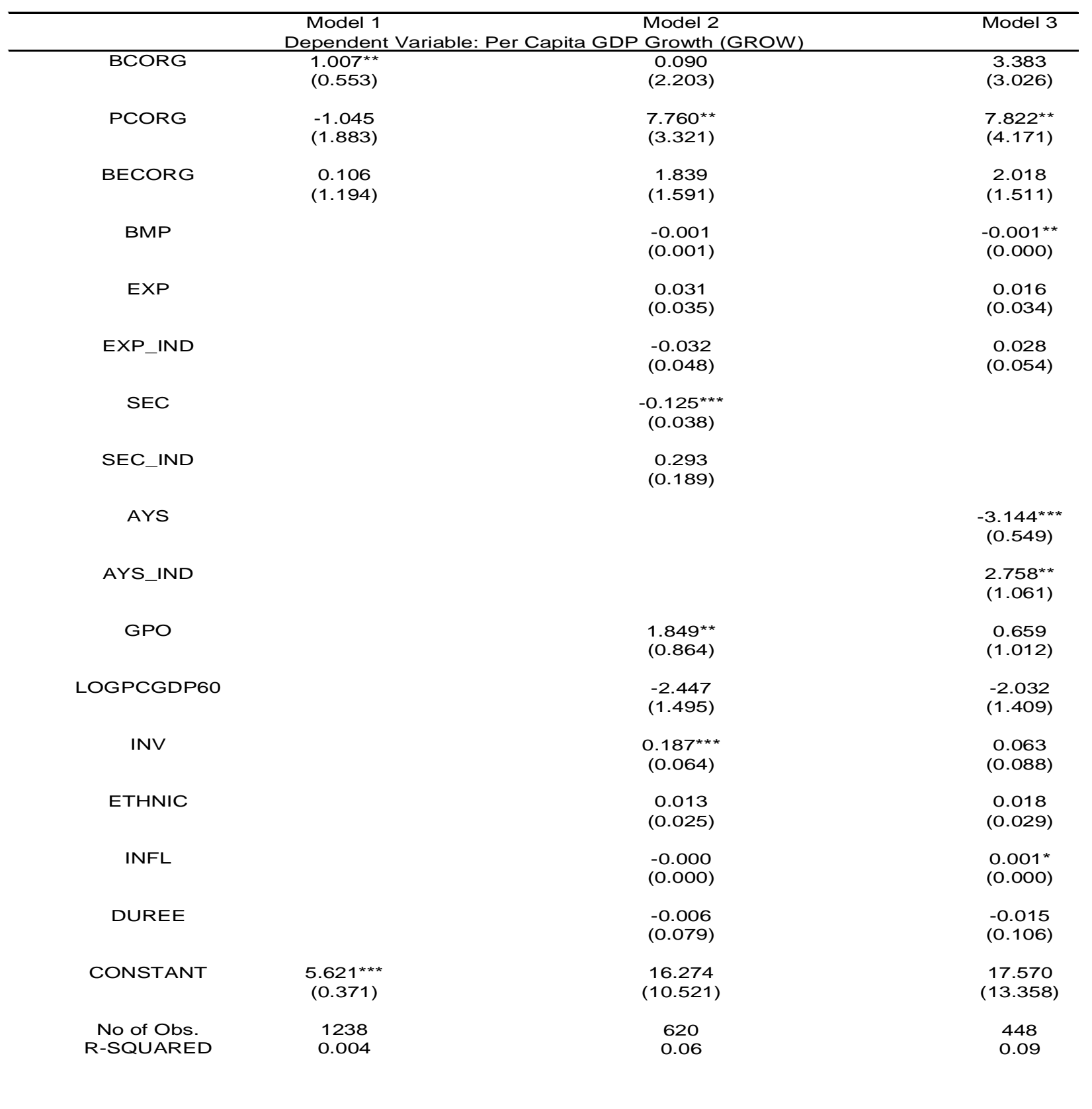

Notes: Robust standard errors are presented in parentheses. ${ }^{\star \star \star}$ significant at the $1 \%$ level, ${ }^{\star *}$ significant at the $5 \%$ level, * significant at the $10 \%$ level. The omitted category is French Colonial Dummy (FCORG).

Source: Author's compilation. 
Table 6: Main results using HT estimator

\begin{tabular}{|c|c|c|c|c|}
\hline & $\begin{array}{l}\text { Deper } \\
\text { Model } 1\end{array}$ & $\begin{array}{c}\text { er Capita } \\
\text { Model } 2\end{array}$ & $\begin{array}{l}\text { ROW) } \\
\text { Model } 3\end{array}$ & Model 4 \\
\hline $\begin{array}{c}\text { Time Variant Exogenol } \\
\text { BMP }\end{array}$ & $\begin{array}{l}\text { riables } \\
\text {-0.001 } \\
(0.001)\end{array}$ & $\begin{array}{l}-0.001 \\
(0.001)\end{array}$ & $\begin{array}{l}-0.002 \\
(0.001)\end{array}$ & $\begin{array}{l}-0.001 \\
(0.002)\end{array}$ \\
\hline $\begin{array}{c}\text { Time Variant Endogenc } \\
\text { INFL }\end{array}$ & $\begin{array}{r}\text { ariables } \\
-0.000 \\
(0.002)\end{array}$ & $\begin{array}{c}0.001 \\
(0.002)\end{array}$ & $\begin{array}{c}0.001 \\
(0.002)\end{array}$ & $\begin{array}{l}0.004 \\
(0.003)\end{array}$ \\
\hline GPO & $\begin{array}{l}1.087 \\
(0.876)\end{array}$ & $\begin{array}{c}1.136 \\
(0.879)\end{array}$ & $\begin{array}{l}0.119 \\
(0.982)\end{array}$ & $\begin{array}{l}0.318 \\
(1.009)\end{array}$ \\
\hline INV & $\begin{array}{l}0.116 \\
(0.088)\end{array}$ & $\begin{array}{l}0.133 \\
(0.088)\end{array}$ & $\begin{array}{l}-0.088 \\
(0.111)\end{array}$ & $\begin{array}{l}-0.049 \\
(0.112)\end{array}$ \\
\hline$E \times P$ & $\begin{array}{l}0.018 \\
(0.056)\end{array}$ & $\begin{array}{l}-0.007 \\
(0.057)\end{array}$ & $\begin{array}{l}-0.005 \\
(0.071)\end{array}$ & $\begin{array}{l}-0.029 \\
(0.072)\end{array}$ \\
\hline SEC & $\begin{array}{l}-0.137^{\star \star \star *} \\
(0.043)\end{array}$ & $\begin{array}{l}-0.251^{\star \star \star} \\
(0.085)\end{array}$ & & \\
\hline SEC_BRI & & $\begin{array}{l}0.173^{*} \\
(0.098)\end{array}$ & & \\
\hline SEC_POR & & $\begin{array}{l}0.813 \\
(1.865)\end{array}$ & & \\
\hline SEC_BEL & & $\begin{array}{l}-0.299 \\
(0.258)\end{array}$ & & \\
\hline AYS & & & $\begin{array}{l}-4.394 * * \star \\
(0.804)\end{array}$ & $\begin{array}{l}-6.974^{\star * \star} \\
(1.648)\end{array}$ \\
\hline AYS_BRI & & & & $\begin{array}{l}3.758^{\star \star} \\
(1.906)\end{array}$ \\
\hline AYS_POR & & & & $\begin{array}{l}13.298 \\
(19.823)\end{array}$ \\
\hline AYS_BEL & & & & $\begin{array}{l}-3.631 \\
(4.391)\end{array}$ \\
\hline $\begin{array}{c}\text { Time Invariant Exogenc } \\
\text { BCORG }\end{array}$ & $\begin{array}{l}\text { ariables } \\
-3.764 \\
(20.834)\end{array}$ & $\begin{array}{c}-9.661 \\
(26.451)\end{array}$ & $\begin{array}{l}5.240 \\
(4.906)\end{array}$ & $\begin{array}{l}-3.615 \\
(7.063)\end{array}$ \\
\hline PCORG & $\begin{array}{l}1.682 \\
(9.914)\end{array}$ & $\begin{array}{c}-6.272 \\
(21.242)\end{array}$ & $\begin{array}{c}6.378 \\
(10.232)\end{array}$ & $\begin{array}{c}-4.463 \\
(22.460)\end{array}$ \\
\hline BECORG & $\begin{array}{l}3.363 \\
(6.995)\end{array}$ & $\begin{array}{l}4.466 \\
(9.079)\end{array}$ & $\begin{array}{c}2.076 \\
(4.022)\end{array}$ & $\begin{array}{l}5.736 \\
(7.767)\end{array}$ \\
\hline DUREE & $\begin{array}{l}0.132 \\
(0.239)\end{array}$ & $\begin{array}{l}0.139 \\
(0.335)\end{array}$ & $\begin{array}{l}-0.012 \\
(0.168)\end{array}$ & $\begin{array}{l}-0.062 \\
(0.187)\end{array}$ \\
\hline LOGPCGDPGO & $\begin{array}{l}-1.204 \\
(16.476)\end{array}$ & $\begin{array}{l}-4.147 \\
(19.686)\end{array}$ & $\begin{array}{l}-1.354 \\
(3.056)\end{array}$ & $\begin{array}{l}-4.209 \\
(3.659)\end{array}$ \\
\hline ETHNIC & $\begin{array}{l}0.057 \\
(0.175)\end{array}$ & $\begin{array}{l}0.093 \\
(0.225)\end{array}$ & $\begin{array}{l}0.037 \\
(0.155)\end{array}$ & $\begin{array}{l}0.103 \\
(0.183)\end{array}$ \\
\hline $\begin{array}{c}\text { Time Invariant Endoger } \\
\text { SEC_IND }\end{array}$ & $\begin{array}{l}\text { Variables } \\
\text { O.607 } \\
(2.576)\end{array}$ & $\begin{array}{l}0.886 \\
(3.195)\end{array}$ & & \\
\hline AYS_IND & & & $\begin{array}{c}4.576 \\
(7.559)\end{array}$ & $\begin{array}{c}7.155 \\
(8.737)\end{array}$ \\
\hline CONSTANT & $\begin{array}{c}-2.550 \\
(97.323)\end{array}$ & $\begin{array}{c}17.345 \\
(114.947)\end{array}$ & $\begin{array}{c}14.989 \\
(20.666)\end{array}$ & $\begin{array}{c}35.111 \\
(27.841)\end{array}$ \\
\hline $\begin{array}{l}\text { No of Obs. } \\
\text { No Groups }\end{array}$ & $\begin{array}{c}620 \\
28\end{array}$ & $\begin{array}{l}620 \\
28\end{array}$ & $\begin{array}{c}448 \\
22\end{array}$ & $\begin{array}{c}448 \\
22\end{array}$ \\
\hline Prob $>$ Chi-square & 0.09 & 0.07 & 0.00 & 0.00 \\
\hline
\end{tabular}

Notes: Robust standard errors are presented in parentheses. ${ }^{* \star}$ significant at the $1 \%$ level, ${ }^{* *}$ significant at the $5 \%$ level, * significant at the $10 \%$ level.The omitted categories are French Colonial Dummies (FCORG, SEC_FRE, and AYS_FRE).

Source: Author's compilation. 